\title{
HOLDING GROUPS: A SAFE CORPORATE STRUCTURE AT THE TIME OF RECESSION
}

\section{Elżbieta RZESZUTEK}

Faculty of Management

Warsaw University of Technology, Warsaw, Poland

e-mail: e.rzeszutek@wz.pw.edu.pl

\begin{abstract}
This article makes a case for holding groups as a type of enterprise structure which guarantees capital and structural security at the time of economic and political transition in the 1990s, which in a way prepared them for the global recession in the early $21^{\text {st }}$ century. The case study of PKN Orlen is presented to illustrate the typical economic developments which accompanied privatisation and commercialisation of Polish state-owned enterprises. A major part of the article addresses management mechanisms which make a holding structure immune to strong economic turbulence which would otherwise be destructive to individual daughter companies.
\end{abstract}

Keywords: holding groups, holding company, holding structure, technical and business aspects of building holding groups, impact of the holding group structure, strategic characteristics of holdings.

1

\section{Introduction}

The current recession forces businesses to search for safe new corporate structures. One such structure which was successfully applied during Poland's transition and EU access is the holding group.

State-owned enterprises were forced to restructure as the country was adopting the market economy. There were three phases of that process. First, companies had to break free from the government's control and learn the rules of market economy with the primary forces of supply and demand and successful performance driven by effective marketing departments analysing the marketplace and manufacturing well aligned with the demand for products and services. This called for a change in the organisational structures and day-to-day operations. Hence, companies were massively restructured and privatised.

The second phase was that of business development and specialisation. Businesses became dependent on market growth and learned to diversify and identify new markets.

In the third phase, companies felt the consolidation pressure as Poland was getting ready for EU membership. Mergers and acquisitions became commonplace. Capital groups were formed to gain more competitive advantage in global markets.

The main benefits of business restructuring included ${ }^{1}$ :

\footnotetext{
${ }^{1}$ Nogalski B., Romanowski R. - Zarzadzanie holdingie. Instytut Organizacji i Zarządzania w Przemyśle (Industrial Organisation and Management Institute), Warsaw 1996, p. 18.
}

- improved timeliness of operational decisions at the level of subsidiaries,

- holding company management not expected to make day-to-date management decisions,

- increased motivation of management teams of subsidiary companies to generate profit and improved accountability,

- improved ability to measure the performance of subsidiaries.

Holding companies manage on a selective basis focusing on certain aspects and areas of the group's activity that are deemed to be critical ${ }^{2}$.

The following sections of the article present:

- the history of the PKN Orlen group since the establishment of the Polish Petroleum Monopoly (Polski Monopol Naftowy),

- mechanisms of managing a holding group as a structure of capital links where the goals and prerogatives of a holding group must be skilfully transposed to the goals and prerogatives of individual subsidiaries in the group,

- technical and economic aspects of the formation of holding groups in the context of political and economic transition of Poland and Central and Eastern Europe,

- the impacts of a holding company on the business of group companies in terms of their research and development, production, procurement and sales;

\footnotetext{
${ }^{2}$ Kreft Z. - Organizacja spótki naczelnej w strategicznym holdingu zarzadzajacym. Wydawnictwo Uniwersytetu Gdańskiego, Gdańsk 1999, p. 114.
} 
- key functions of the holding company with respect to managing operations, group development and effective share holding structure,

- strategic qualities of holding structures when used as economic restructuring tools with decentralised management functions of the entire holding group and its individual member companies.

\section{Case study: PKN Orlen}

The history of the company begins in July 1944 with the establishment of an organisation responsible for securing the petroleum infrastructure that had survived WWII and the Nazi occupation and for restoring the distribution system. The first government decree establishing the Polish Petroleum Monopoly (Polski Monopol Naftowy) was issued on August 14, 1944. However, the name was changed in October of the same year into State Bureau for Petroleum Products Sales (Państwowe Biuro Sprzedaży Produktów Naftowych $)^{3}$. Central Office of Petroleum Products (Centrala Produktów Naftowych) was established in December 1945. The organisation was again renamed ten years afterwards into "CPN" Central Management for Trade in Petroleum Products (Centralny Zarzad Obrotu Produktami Naftowymi "CPN"). The previous name was restored plus its acronym was added three years later Centrala Produktów Naftowych "CPN". In December 1995, CPN was restructured into a joint-stock company wholly owned by the State Treasury, which was reflected in the "S.A." (Spótka Akcyjna) added to its name. At the end of its life, the company owned a network of more than 1400 petrol stations and a fleet of over 600 tanker trucks for transporting fuels.

The political change which began in the 1980s in Poland gave rise to the adoption of market economy in the country. On July 1, 1993, Mazowieckie Zakłady Rafineryjne $i$ Petrochemiczne (MZRiP) (Masovian Refinery and Petrochemical Works), which had been established on December 1, 1959, was transformed into a joint-stock company called Petrochemia Płock S.A. In May 1998, the Council of Ministers (the Government) took a decision to form a national petroleum corporation by merging Centrala Produktów Naftowych CPN S.A. and Petrochemia Płock S.A. Polski Koncern Naftowy S.A. was formally established

\footnotetext{
${ }^{3}$ http://www.orlen.pl/PL/OFirmie/Nasza\%20historia/Strony/ Historiaslowami.aspx
}

on December 7, 1999 as a petroleum processing and oil derivatives distribution group of companies.

The group includes oil refineries in Poland (Płock, Trzebinia, Jedlicze), three in the Czech Republic and one in Lithuania (Mažeikiai). Orlen signed an agreement with the National Assets Fund of the Czech Republic in June 2004 whereby it became a majority shareholder $(63 \%)$ of the Czech Unipetrol a.s. group of companies in the oil processing and fuel distribution sector. The Company operated a network of 338 premium and economy petrol stations as at year end 2011. The number of Benzina Plus premium stations offering a broad selection of non-fuel products and services increased from 113 to 115 in 2011 . There were 223 sites in the economy sector.

As at year end 2011, ORLEN Deutschland operated a network of 567 petrol stations, of which 541 under the STAR brand in the economy sector, 25 stations adjacent to hypermarkets and on premium site.

The group now includes the following companies: ORLEN Księgowość (shared accounting services centre), Basell ORLEN Polyolefins (plastics and synthetic materials), ORLEN (petrol station brand in the Polish and German market), UniPetrol (Czech refinery group), Benzina (petrol station brand on the Czech market), Solino (manufacturing of industrial brine and underground storage of oil and oil derivatives), Anwil (a chemical company in Poland), ORLEN KolTrans (rail transport and haulage), ORLEN Lietuva (a refinery in Lithuania), ORLEN Transport (transport of petroleum products), ORLEN Lietuva (a petrol station brand on the Lithuanian market), ORLEN Oil (oil supplier), ORLEN Gaz (gas producer), SHIP SERVICE (marine fuels), Bliska (a petrol station brand on the Polish market), Star (a petrol station brand on the German market), Benzina Plus (an economy petrol station brand on the Czech market), Ventus (an economy petrol station brand on the Lithuanian market), Rafineria Trzebinia (refinery in Trzebinia, Poland), Rafineria Jedlicze (Refinery in Jedlicze, Poland), ORLEN Ochrona (security company), ORLEN Prewencja (ocupational health and safety services, fire prevention services and environmental services) merged with ORLEN Eko, ORLEN Petrocentrum (a brand on the Polish market), ORLEN Laboratorium, ORLEN Asfalt (asphalt producer), ORLEN Automatyka (industrial automatic control systems), ORLEN Administracja (services), ORLEN Wir (rotating machines), ORLEN Medica (medical services), ORLEN Budonaft (petrol 
station construction), Spolana (chemical company in the Czech Republic), ORLEN International Exploration and Production Company (international oil exploration and development), ORLEN Upstream (domestic oil exploration and development).

ORLEN's retail business relies on efficient logistics network including overground and underground storage and long-distance pipelines. The group holds a licence for onshore and offshore oil and gas exploration across Poland and one of its priorities is unconventional gas exploration. A panel of experts from subsidiaries ORLEN Upstream Sp. $\mathrm{z}$ o.o. and ORLEN International Exploration and Production Company BV reviews an average of 80 exploratory projects a year in Central Europe, Africa, Middle East, North America and the Caspian Sea Basin.

The history of PKN Orlen is the best proof of the efficiency of the holding group structure. With its diversified business profile, the group can generate revenues from a number of different sources and it has grown to become one of the leaders and largest corporations in the oil industry in Central and Eastern Europe.

\section{A holding group: group management mechanisms}

Unlike in capital groups where member organisations may be related to each other based on contracts, agreements or equity links, mutual relations between organisations in a holding group are based on equity links ${ }^{4}$.

The structure of a holding group derives from equity linkages. An organisation may play a superior role in the group if it holds stock in other subsidiaries in the group or a subordinate role if its stock is owned by another company. A holding group consists of:

- a holding company (controlling entity),

- one or more subsidiary companies (controlled entities).

The holding company is also referred to as the mother company and subsidiaries as daughter companies. The holding company has the following powers:

- it holds a controlling stock,

- it controls and supervises subsidiaries,

\footnotetext{
${ }^{4}$ Holding group - a group of enterprises where one of the them is superior over the others. Leksykon zarządzania (ed. M. Adamska), Difin, Warsaw 2000, p. 161.
}

- it has the voting right in the bodies of its subsidiaries.

The rights of subsidiaries are defined in the holding agreement. Holding agreements concluded with each subsidiary define:

- the share of the holding company in the subsidiary's assets,

- the right to exercise permanent control over the subsidiary's management, business and legal affairs,

- the persistency of the holding relationship (the acquisition of shares is of a definitive nature),

- additional provisions (future collaboration, position etc.).

The holding structure is complex and clearly defined group objectives must be adequately transposed into the objectives of each of the subsidiaries. Thus, the nature of a holding is the control over the business of other companies through equity exposure. The goal of such control is to:

- shorten the decision-making paths,

- manage certain areas of business on a shared basis for all the companies with the group,

- reduce overhead expenditures,

- improve the efficiency of innovation cycles,

- ensure consolidated financial reporting.

The powers of each group member must be clearly defined and they will depend on the functions of each subsidiary in the group. Holdings are complex structures. Jung lists the following prerogatives of the holding company:

- engage in business activity on its own account and risk,

- accumulate and redistribute part of the profit generated by subsidiaries,

- exercise control over the business and financial performance of companies through managing their balance sheets and profit and loss accounts,

- address issues related to international and domestic distribution and ensure adequate service infrastructure (to maximise efficiency),

- initiate and develop business development and modernisation programs jointly with individual subsidiaries to improve the efficiency of revenue generation by engaging in financing and creation of new companies, 
- analyse and initiate the adoption of management and information systems in subsidiaries to improve efficiency and productivity,

- conduct or outsource research and analyses using international or Polish consultancies,

- represent the holding company in supervisory boards of subsidiaries,

- define the role of the holding company in appointments to top management positions in subsidiaries.

The holding company is thus empowered to operate in the following dimensions:

- strategic planning,

- operational control,

- management control.

Strategic planning is vital in a holding structure. It allows the holding company to decide on the key objectives of the entire organisation and define ways of implementing them. The objectives are defined as financial targets to be achieved and/or maintained (equity growth rate) and as positioning targets (position within the group).

Operational control lies within the units of the holding company and applies to individual task and transactions. It may also lie within subsidiary companies.

Finally, management control is exercised in order to supervise and effectiveness and efficiency of strategy implementation with the main focus on the efficiency of program delivery and centres of accountability, i.e.:

- cost centres managed by administration, legal and accounting departments with respect to planned (predictable) cost such as inputs, labour and unplanned cost (revenue centres at the discretion of management),

- profit centres (subsidiary companies),

- investment centres.

The efficient operation of a holding group depends on the quality of information handled internally and externally to support the best possible planning and decision-making in the interest of the organisation. Economic analyses conducted by the organisation are a crucial source of information which feeds into business development and investment policies of a holding group.

The holding group is a structure which improves the efficiency of equity management and allows the group to venture into higher risk business opera- tions. Holding companies can:

- ensure transitional funding where one subsidiary may support others within the group,

- avoid limitations related to antitrust legislation,

- spread investment risks,

- create new businesses (companies) at a lower risk for external investors.

Both new companies aspiring to gain a significant market position and large corporations which cannot be efficiently managed because of its size may find forming a holding group a viable business proposition. Decision-making becomes decentralised in a holding group. Moreover, a holding group:

- creates an opportunity to effectively use the equity of one entity to support another in consideration of a share in its profits,

- introduces and mobilises free non-investment capital,

- may be used as a vehicle to obtain good terms on loans to support projects identified by the equity holder,

- has its own management and legal independence (may have) linked to a specific asset, civil and penal accountability,

- is an effective means of concentrating equity and economic decision-making (benefits from central policy, tax optimisation and capital flows between group members),

- enjoys additional benefits related to the construct of the holding company (a wholly-owned limited liability company), which legally separates "personal" and company assets.

However, there are some disadvantages to a holding structure. First, it has not existed in the economy long enough and its members often lack extensive experience too. There is no detailed legislation in place. Some of the negative aspects of holding structures are:

- lack of control over the linkages within the system: lack of full control in critical situations,

- low level of protection for shareholders in subsidiary companies: possible abuse of majority rights,

- limited communication between shareholders (the mother company is the only one to have access to all information: this allows manipulation between the companies,

- available option to form a wholly-owned partnership: this limits the rights of others, 
- given their equity position, subsidiary companies are perceived as hostages of the mother company,

- with the personal links in place, such structures are examples of monopolistic practice.

The holding groups listed below had different origins. Some emerged out of the restructuring of foreign trade enterprises (centrala handlu zagranicznego), a special type of state-owned enterprises in the Eastern bloc allowed to engage in the exportation and importation of goods and services and settling in 'hard' currency, e.g. Agros. Other, such as Hortex or Stalowa Wola, resulted in the transformation of existing 'combines' or industrial conglomerates.

The newly formed holding groups have been confronted with the need to develop effective group management methodologies. The experience in recent years demonstrates that executives in a number of companies that operate as part of holding groups do not fully appreciate the specificity of such group structures, particularly in terms of management approach.

While there have been a number of successfully operating holding groups there is still a gap to be filled with respect to effective and efficient management. Implementing relevant management systems to ensure effective control over the company and its business is nothing else than developing and enforcing a set of internal documents that provide detailed descriptions of such management systems, define their scope and specify the roles and responsibilities of the company officers and executives. Having such management systems in place ensures management accountability.

A formal structure is critical for management systems to be properly anchored in the organisation. Both delegating tasks and responsibility should be formally regulated in the organisation. This helps eliminate the phenomenon of collective accountability and improves the efficiency of managing company resources.

\section{$4 \quad$ Holding groups in manufacturing and food processing industries: technical and business aspects of building holding groups}

Industrial holding groups are complex structures consisting of a number of diverse business organisations with different profiles (manufacturing different products, delivering different services etc.).

There are high-growth holding groups in the food processing and other industries in Poland. The following section presents holding groups in food processing, machine and plastics industry. These holding groups have evolved in a number of different ways.

Holding groups in food processing have emerged in one if two ways:

- the Agros Group came into being following the restructuring of a foreign trade enterprise,

- the Hortex Group is a result of a transformation of an industrial conglomerate into a limited liability company then converted into a holding company after privatisation.

The Agros Group is an example of a holding group resulting from the restructuring of a foreign trade enterprise $^{5}$. The foreign trade enterprise had lost most of its markets in the late 1980s. Like other foreign trade enterprises under communism, Agros had its suppliers and customers and a specified (dedicated) assortment, in this case food products. The enterprise generally engaged in trading goods. In 1992, 70 per cent of the enterprise's revenue came from international trade. The main focus of its restructuring was vertical and some horizontal diversification. The business was broadened to include purchasing of produce, processing, storage and sales on the domestic and international markets. These changes helped the group restructure its revenue streams in 1995: trade accounted for less than 50 per cent, 33 per cent from processing and the remainder from distribution. The Agros Group became one of the largest producers of fruit and vegetable products. It has a captive distribution network and owns such well known brands as "Krakus" (fruit and vegetable products), "Fortuna" (juices), "Lowicz" (jams), "Ptyś" for carbonated drinks and many other. Agros owns several major food processing plants and it has recently expanded into the dairy and meat sector.

The Agros Group has a strong position with 25 per cent market share in the juice market, 20 per cent in concentrated juice, 70 per cent in vegetable juice, 50 per cent in jam and around 20 per cent in the apple squash market. The policy of vertical diversification pursued by the group (it is considering widening its "Krakus" and "Fortuna" portfolios) is continued and has recently been supplemented by horizontal expansion into dairy and meat products).

The Agros Group is one of the top ten companies listed on the Warsaw Stock Exchange in terms of capitalisa-

\footnotetext{
5 Romanowska M., Trocki M., Wawrzyniak B. (ed.) - Grupy kapitalowe w Polsce. Difin, Warsaw 2000, p. 213.
} 
tion and is ranked 42 on the Financial Times list of leading businesses in Central and Eastern Europe.

Agros Holding S.A. is the equity and financing hub whose role is to make strategic decisions affecting the entire organisation and to manage the subsidiary companies. With centralised management of finance, organisation, marketing and production, the Management of Agros Holding S.A. pursues the strategy of seeking economies of scale and equity concentration benefits. It also seeks to enhance its marketing function by consolidating category and bran management.

The Agros Group is planning to acquire more businesses as they become available as privatised entities. It allocates a major budget to new acquisitions to strengthen its position in the domestic market and expand to international markets. It is planning to upgrade its distribution system and apply the latest sales techniques in major Polish cities. The goal of the Agros Group is to obtain ISO 9000 certification by implementing a quality assurance system and environmental projects. This will help the group enhance its position in international markets.

Holding groups in the machine industry have mainly resulted from restructuring processes as the heavy industry faced significant challenges during Poland's economic and political transition in the late 1980s. Companies in the steel, shipbuilding, defence, mining, heavy machinery and installations and construction industries suffered from the loss of their existing customer base in the East and other countries of the Eastern bloc where transition weakened the local economies. Polish enterprises experienced difficulties collecting their receivables for exported goods and services.

To save the endangered enterprises the government transformed them into holding groups. The main goal was ensure that the existing industrial conglomerates could successfully operate in the market economy.

The creation of a holding group helps companies improve their competitive position, leverage the experience of other group members and engage in joint projects, e.g. research and development in the area of new designs, technologies, manufacturing methods etc. More opportunities that come with more resources available to companies help companies in holding groups boost their performance.
According to M. Trocki, being part of a holding group allows companies to implement a series of fundamental functions:

- operational management,

- capital group development,

- share management.

Operational management reflects the technical benefit from the transformation of an enterprise into a holding group. The other two functions reflect the economic benefits.

\section{Impact of the holding group structure on the business of subsidiaries}

With regard to operations, a holding structure ensures better technical means for the entire group and individual subsidiaries. The barrier of constrained resources can be more easily overcome and resources become easier to manage. Operations include both the core business and ancillary activities. Here is the illustration of both types of operational activity in manufacturing. The following are the core business activities:

- research and development (often done by a shared R\&D facility which could otherwise not be affordable to individual companies),

- procurement (joint procurement reduces cost and contribute a more rational use of resources and allows the group to help those subsidiary companies which face procurement challenges),

- production (joint production of goods, production collaboration and support),

- sales (joint sales policy implemented by a trading company or by specialised dealers or sales units or by external traders.

With regard to ancillary activities, the following can be done jointly by companies in a holding group:

- inputs management (joint management of inputs within the existing structure),

- transport management (a transport company can provide its services to other companies within the group),

- fixed asset and workshop management (this can be done a specialised company or plant within the group),

- energy (e.g. an electricity distribution company may exist within the group and serve other subsidiaries),

- quality control (a share quality department), 
- environmental controls (the high cost of environmental performance it is critical to have a specialised environmental laboratory and environmental department in the group),

- general administration (shared administration of the entire group and its subsidiaries.

Being part of a holding group helps individual companies enhance their operations. The above operational management and group development management functions have a positive impact on business performance. All specific tasks performed within the operations management function must be considered as they contribute to the overall success of the holding group concept. Here is a list of such operational tasks:

- activity planning for the entire group and to some extent (different in different holding groups) for individual companies,

- organising activities - like in planning, it applies to the entire group and its subsidiaries; the aim is to achieve performance targets,

- investment projects implemented by the mother company using resources developed by the entire group (e.g. internal financing),

- personnel (human resources) management - effective use of highly specialised personnel,

- finance management - effective use of funds generated within the group,

- internal audit - a task performed by specialised personnel to identify irregularities which may hinder performance and to identify corrective actions,

- marketing - a dedicated department develops a strategy for the entire holding group and individual subsidiaries to ensure high profits,

- public relations for the entire holding group and all individual companies.

Individual business performance of subsidiaries in a holding group is vitally important as is market positioning. Therefore, groups need to focus on their business development function with such individual tasks as:

- setting goals and objectives (identify the business area, the competitive position and other growthoriented parameters),

- develop a strategy for the group and strategic guidelines for subsidiaries (identify targets to measure performance against the strategy),
- engage in new types of business and exit existing businesses (non-portfolio); develop businesses which promise strong performance,

- organise the holding group - establish a structure to ensure effective management,

- distribute funds to support the activities of group members (this includes investment funds) to improve the economic performance of supported companies,

- define and manage human resources policies in companies (management) to influence and control their operations,

- attract strategic investors for subsidiaries,

- ensure recovery in companies facing major business challenges by injecting capital generated elsewhere in the group,

- manage the transfer of know-how (between companies in the group) to leverage the experience within the group,

- coordinate and centrally manage the key functions: $R \& D$, finance, investments, implementation etc. They are extremely costly but indispensible for the group to maintain its market position,

- review the operations of subsidiaries in terms of their performance against strategic objectives (strategic controlling) to measure the level of economic success.

Share management is a function that seeks to achieve and economically viable distribution of shares in the group. The following are some of the specific tasks in this function:

- define the rules and objectives of share management (to be defined by the owner(s)),

- buy/sell shares (according to existing rules and guidelines),

- attract new investors to subsidiaries (to improve their competitive position and to ensure access to state-of-the-art design, technologies and manufacturing techniques),

- maintain shareholder relations to meet financial targets (define the rules of collaboration and control),

- define profit distribution policy (to reflect level of contribution made by each company in the group), 
- review the financial performance of subsidiaries and ensure coordination of activities in this area (supervise for adequate utilisation of available resources),

- mobilise financial support for subsidiaries (mobilise free capital outside of bank financing and control),

- provide internal loans (using capital developed by group members),

- manage clearing and settlement of intra-group transactions and ensure their compliance,

- coordinate financial reporting of subsidiaries and report on a consolidated basis,

- provide financial advice to subsidiaries through specialised departments in the holding company.

\section{$6 \quad$ Holding as a restructuring tool: strategic characteristics of holdings}

The restructuring processes affect a variety of enterprises in Poland. A large group of restructured enterprises are former 'combines' or conglomerates. They had to be restructured according to carefully selected rules because of the size of their assets and the type of business. Out of many other available restructuring options, the holding group approach was adopted in cases such as Huta Stalowa Wola (steelworks) or Petrochemia Płocka (petroleum company). This approach allowed decentralisation and demonopolisation, and facilitated the adoption of an efficient structure which generates profit and warrants a significant market position.

A holding group-oriented restructuring allowed the creation of spin-offs which became separate entities with full accountability for their financial performance. This fuelled initiative and entrepreneurship as spin-off companies (subsidiaries) were delegated rights and responsibilities. The decentralisation of responsibilities lead to the enhancement of decision-making processes in the subsidiaries and a better distribution of risk from one enterprise into individual spin-offs depending on the type of their business.

The decentralisation process resulting from the transformation into a holding structure affected the following aspects:

- delegation of responsibilities and powers to subsidiaries,
- operations management at the level of subsidiaries, which supported their conversion into profit centres,

- higher prestige of the management of independent companies.

This contributed to improved efficiency and entrepreneurship and increased the motivation and commitment of staff who identified themselves with their organisation. The powers and responsibilities delegated to such independent entities made them easier to manage. The cost and benefit analysis became possible, which entailed a much more rational use of resources.

Holding structures operate in line with strategies. These strategies differ from those for individual enterprises. There are two strategic levels:

- individual strategy of a company which is part of a group,

- group strategy.

The group strategy is that of the mother (holding) company which manages daughter (subsidiary) companies to increase their value. This process is called corporate parenting. The group strategy concentrates on three fundamental areas (supporting value growth):

- portfolio management,

- core business competencies (companies),

- improved financial performance of individual companies.

Fig. 1 illustrates the links between the group (corporate) strategy and the strategies of individual subsidiaries in a holding group. The corporate strategy guides the individual strategies of group subsidiaries. Individual strategies reflect the general strategy and must not stand in conflict with it.

\section{Conclusions}

The high position and performance of the holding groups presented in this article provide the best case for the concept. Here are some detailed benefits related to holding group structures:

- financial - reduced overhead cost, accumulation and redistribution of profit generated by subsidiaries, availability of transitional cross-financing within the group, 


\section{Increase in Value}

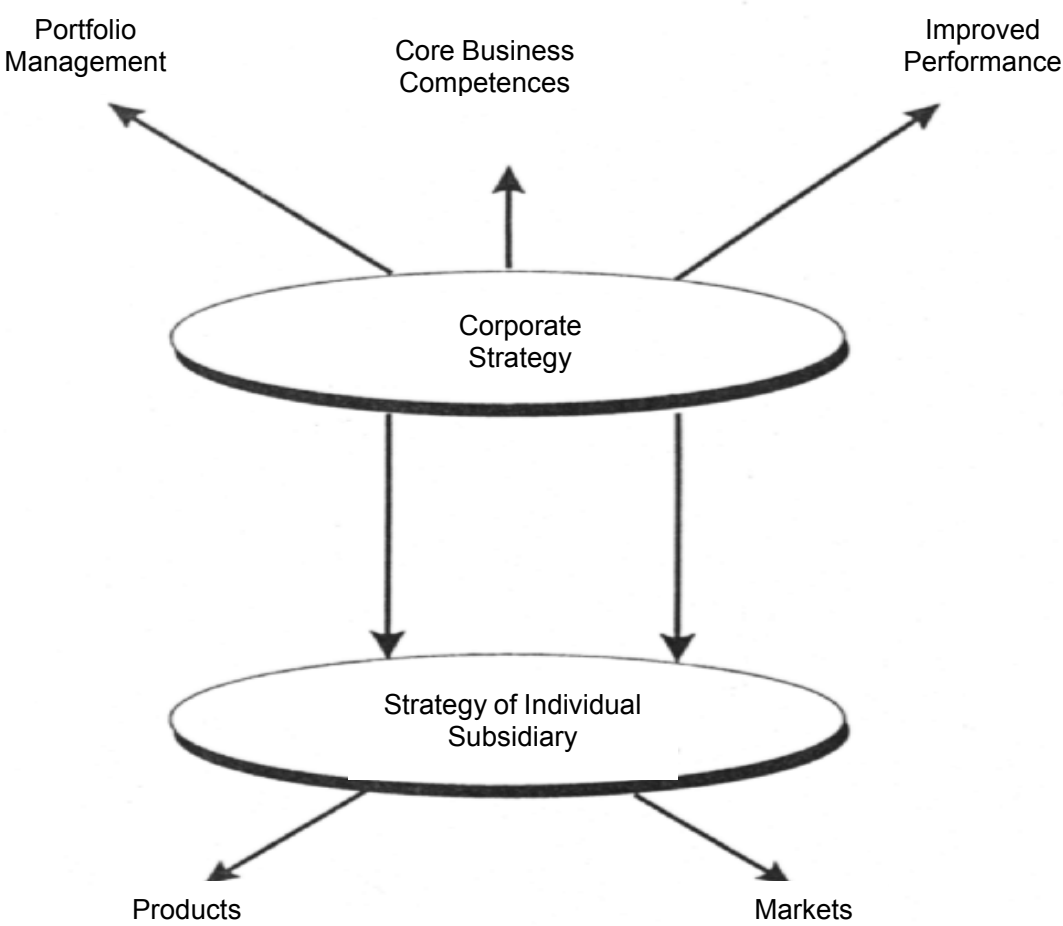

Developing a Significant and Sustainable

Competitive Advantage

Fig. 1. Individual Strategies of Holding Group Members

(source: [6, p. 31])

- organisational - organising forms or channels of domestic and international distribution, initiating and developing development and modernisation programs for subsidiaries, research and development, business analytics performed by specialised companies (Polish or international), organising procurement and ancillary functions (e.g. transport) and environmental controls,

- effective group functions in the area of operations management, group development management, and knowledge and human capital management,

- strategic features of a holding group as a tool of economic restructuring leading to decentralised management functions.
With the above-mentioned functions performed by the mother company, daughter companies can reduce their cost base and become more competitive in the domestic and international market.

\section{$8 \quad$ References}

[1] Abramowicz W. - Zintegrowane systemy informacyjne, Zintegrowane systemy zarzadzania. Narzedzia do efektywnego zarzadzania przedsiębiorstwem. Vogel Publishing, Wrocław 2007.

[2] Abt S. - Zarzadzanie logistyczne w przedsiębiorstwie. Polskie Wydawnictwo Ekonomiczne, Warsaw 1998. 
[3] Bieniok H i inni: Metody sprawnego zarzqdzania. Planowanie, organizowanie, motywowanie, kontrola. Agencja Wydawnica „Placet”, Warsaw 1997.

[4] Chauvet A. - Metody zarzqdzania - przewodnik. Poltext, Warsaw 1997.

[5] Durlik I. - Restrukturyzacja procesów gospodarczych. Reengineering teoria $i$ praktyka. Agencja Wydawnicza „Placet”, Warsaw 1998.

[6] Ellis J., Williams D. - Strategia przedsiębiorstwa a analiza finansowa. FRR, Warsaw 1997.

[7] Gierszewska G., Romanowska M. - Analiza strategiczna przedsiębiorstwa. Polskie Wydawnictwo Ekonomiczne, Warsaw 1998.

[8] Grudzewski W.M., Hejduk I. - Formy organizacyjno-prawne grup kapitałowych [in] Organizacja i Kierowanie, No. 4, 1998.

[9] Grudzewski W.M., Hejduk I. - Holdingi w kluczowym przemyśle $w$ Polsce. Koncepcje struktur, przekształcenia własnościowe [in] Organizacja i Kierowanie, No. 3, 1998.

[10] Haus B. - Organizacja i funkcjonowanie przedsiębiorstw wielozakładowych. Polskie Wydawnictwo Ekonomiczne, Warsaw 1975.

[11] Kupczyk A., Korolewska-Mróz H., Czerwonka M. - Radykalne zmiany $w$ firmie. Od reengineeringu do organizacji uczacej się. Wydawnictwo PrawnoEkonomiczne Infor, Warsaw 1998.

[12] Kreft Z. - Organizacja Spółki Naczelnej w Strategicznym Holdingu Zarzadzajacym. Wydawnictwo Uniwersytetu Gdańskiego, Gdańsk 1999.

[13] Lambert T. - Problemy zarzadzania. 50 praktycznych modeli rozwiazań. Dom Wydawniczy ABC, Warsaw 1999.

[14] Leksykon Zarzqdzania. (ed. M. Adamska) - Difin, Warsaw 2000.
[15] Masłyk-Musiał E. - Zarzqdzanie zmianami $w$ firmie. Centrum Informacji Menedżera, Warsaw 1996.

[16] Muhlemann A.P., Oakland J.S., Lockyer K.G. Zarzadzanie. Produkcja $i$ ustugi. Wydawnictwo Naukowe PWN, Warsaw 1995.

[17] Nizard G. - Metamorfozy przedsiębiorstwa. Zarzqdzanie $w$ zmiennym otoczeniu organizacji. Wydawnictwo Naukowe PWN, Warsaw 1998.

[18] Nogalski B. i inni - Holding jako formuła restrukturyzacji przedsiębiorstwa wielozakładowego. Wyższa Szkoła Administracji i Biznesu w Gdyni, Gdynia 1996.

[19] Nogalski B., Ronowski R. - Holding czyli o instytucji szczególnie efektywnej w pewnych sytuacjach. Instytut Organizacji i Zarządzania w Przemyśle „Orgmasz”, Warsaw 1994.

[20] Nogalski B., Ronowski R. - Zarzqdzanie holdingiem. Instytut Organizacji i Zarządzania w Przemyśle „Orgmasz”, Warsaw 1996.

[21] Penc J. - Strategie zarzadzania. Strategie dziedzinowe $i$ ich realizacja. Zintegrowane zarzadzanie strategiczne. Agencja Wydawnicza „Placet”, Warsaw 1995.

[22] Romanowska M., Trocki M., Wawrzyniak B. (ed.) - Grupy kapitałowe w Polsce. Difin, Warsaw 2000.

[23] Romanowska M. - Alianse strategiczne przedsiębiorstw. Polskie Wydawnictwo Ekonomiczne, Warsaw 1997.

[24] www.agros.com.pl

[25] www.firstnif.com.pl

[26] www.hortex.com.pl

[27] www.magnapolonia.com.pl

[28] www.nifeksa.com.pl 